\title{
DEPRECIATION OF ANIMALS AND ECONOMIC RETURN: CASE STUDY
}

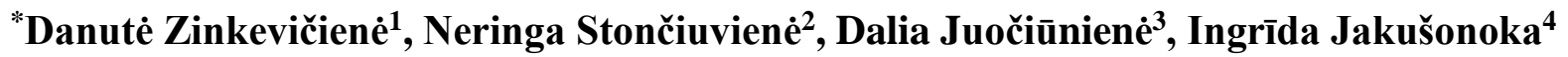 \\ ${ }^{1}$ Prof. Dr. Vytautas Magnus University. K. Donelaičio Street 58, 44248 Kaunas. Lithuania. Phone \\ +370(616) 09 279. E-mail danute.zinkeviciene@vdu.lt \\ ${ }^{2}$ Prof.Dr.Vytautas Magnus University,E-mailneringa.stonciuviene@vdu.lt \\ ${ }^{3}$ Assoc. Prof. Dr. Vytautas Magnus University, E-mail dalia.juociuniene@vdu.lt \\ ${ }^{4}$ Prof. Dr. Latvia University of Life Sciences and Technologies, E-mail ingrida.jakusonoka@llu.lv
}

Received 3105 2019; Accepted 30062019

The article is relevant due to the different prevailing practices of calculating the depreciation of biological assets in different countries. There is also no substantiated answer in scientific research to the following questions: is it necessary to calculate the depreciation of animals, used in agricultural activity, and what is the impact of depreciation of animals' calculation/non-calculation on economic return? Purpose of the article is to assess the impact of the accounting of animals at their acquisition (production) cost less depreciation to the financial results and economic return of agricultural businesses. It is a case study, based on analytical data from agricultural businesses, that specialise in animal breeding and value the animals at the acquisition cost, however do not calculate depreciation. The methods used for the research are analysis of accounting registers analytical data as well as calculation and analysis of selected financial ratios to assess the effect of animal depreciation on the book values of animals and significance of the indicators of economic return. Research results reveal that the gradual write-off of the cost of livestock in the form of depreciation is not reasoned, because it does not take into account the changes in the economic value of the animals. Additionally, as shown by the results of the case study, in order to improve the solvency (i.e. liquidity and stability), reduce the financial risk, and increase economic return, the most attractive alternative from the financial perspective is to measure the livestock at the acquisition (production) cost and to waive the depreciation accounting.

Keywords: animal classification, animal measuring, measuring at cost, depreciation, financial standing, results of the activity.

JEL Codes: D24, M41, Q14.

\section{Introduction}

In agribusiness, animals represent a large proportion of biological assets. Those assets can be characterised by some very specific features: biological transformation, agricultural produce or other biological assets arising from biological assets or animals consumed as produce. Animals can be reared for periods ranging from some months to several years, which gives rise to concern about their correct classification and measuring. Following the implementation of Directive 2013/34/EU (the Accounting Directive), a requirement to record animals and other biological assets in the balance sheet as current or non-current assets depending on the period of time or nature of economic benefit must be applied.

Copyright (C) 2019 The Authors. Published by Vytautas Magnus University, Lithuanian Institute of Agrarian Economics. This is an open-access article distributed under the terms of the Creative Commons Attribution-NonCommercial 4.0 (CC BY-NC 4.0) license, which permits unrestricted use, distribution, and reproduction in any medium, provided the original author and source are credited. The material cannot be used for commercial purposes. 
The Accounting Directive provides that the acquisition/production cost of noncurrent assets with limited useful economic lives shall be systematically written off (depreciated) over their useful economic lives.

When considering depreciation accounting for animals, the problems are related to animal classification and their measuring at cost. Animal classification has to take into account their specificities, which distinguish their classification from the classification of other assets. One of the key factors in attributing assets to the noncurrent asset group is their period of use. In the meantime, species of animals are characterised by a specific life/production cycle defined as the process of animal growth, ageing, and use for production of agricultural products or generation of new biological assets. Biological transformation depends on growth risks caused by natural processes, which are typically too difficult for people to control (Sedláček, 2010). In agricultural production, it is not uncommon that animals, which are intended to be used for an extensive period, have to be prematurely discarded due to insufficient productivity, diseases or disasters. According to Demir (2015), specific aspects of agricultural accounting and issues related to applying common accounting rules in agriculture are among the main reasons leading to erroneous measurement of agricultural activity.

The issue of biological asset classification is widely analysed in scientists' works. Huffman (2016), Botosan (2015), Bohušová (2014), Kurniawan (2014), Gjoni (Karameta) (2013), Aryanto (2011), Vazakidis (2010), Pop (2008) propose classification of biological assets based on economic perspective. To this end, they suggest that biological assets should be classified into two groups: bearer biological assets and consumable biological assets. Gonçalves (2015) claim that since 1 January 2016 such classification has also been provided for in IAS 41. Bearer biological assets are those, which bear agricultural produce or other biological assets, while consumable assets are those, which are to be sold as biological assets (Yazarkan, 2016; Kurniawan, 2014). Fischer (2013) note that animals can become consumable assets even if they are reared for several years as they may be sold at any time during their growth, e.g., sheep or goats. The main differences between bearer biological assets and consumable biological assets are that bearer biological assets provide benefits for a longer period than consumable biological assets (Huffman, 2016), whereas consumable biological assets are sold within a relatively short period of time (Gonçalves, 2015).

Furthermore, Aryanto (2011) identifies mares and laying hens as an example of bear biological assets. He argues that the key determinant for biological assets to be classified as bearer biological assets is the purpose for which they are farmed. Under the provisions of the Romanian accounting regulations, self-regenerating biological assets are classified as bearer biological assets (Sava, 2014). Current biological assets include offspring of all animal species and reared young animals, animals and birds for slaughtering, bee families, and animals that will generate agricultural produce in the future: wool, milk or fur (Ocnean, 2017). A similar practice is set out in Lithuanian BAS 17 (2016), Germany (Krudewig, 2017; Schieder, 2016), and Czech Republic (Sedláček, 2010). 
Although IAS 41 Agriculture (IAS 41) provides for only one method of measurement for biological assets, i.e. at fair value less estimated costs to sell, analysis of international practice of accounting for biological assets described in scientific literature (Otavova, 2017; Riccardi, 2016; Scott, 2016; Fischer, 2013) demonstrates that international accounting regulations are not strictly observed, and national standards of different countries provide that those assets should be measured at cost. The cost model is a priority in the United States (Fischer, 2013; Bohušová, 2012), Latvia (Rozentāle, 2013, Ore, 2011), the United Kingdom, Canada, France (Bohušová, 2012; Aryanto, 2011), Romania (Feleagă, 2012), etc.

In Lithuania biological assets can be measured either at costs or at fair value less costs to sell. A survey conducted in 2014 shows that about 86 percent of Lithuanian businesses responding to the survey measured their animals and other biological assets at cost (Audit and Accounting Service, 2014). Consequently, the choice of different biological asset measuring models complicates the comparison of information and raises a question as to the correct way of presenting those assets in the financial statements. Scientific research related to the accounting for animals used in farm activities asks: a) is it relevant to depreciate animals used in farm activities? b) should depreciation be calculated for all or only some of those animals? c) what should the minimum value be for the purpose of depreciation accounting? (Demir, 2015). There are no easy answers to those questions as they are related to the differences in tax legislation and financial accounting.

Analysis of scientific literature (Huffman, 2016; Riccardi, 2016; Botosan, 2015) demonstrates that when animals are measured at cost, the practices related to depreciation accounting differ. Huffman (2016), Riccardi (2016), Botosan, (2015), Feleagă (2012), Sedláček (2010) argue that in financial statements animals for production should be reflected at actual cost less any accumulated depreciation. Whereas other authors suggest that depreciation of productive animals should not be accounted for since the residual value fails to correctly reflect the real value of the assets (Georgieva, 2016; Visberg, 2016; Newport, 2015). In Lithuania most agricultural enterprises measure all animals at cost, however, they do not calculate depreciation (Martirosianiene, 2016).

By reference to the practice of accounting for biological assets in Romania and Czech Republic, Feleagă (2012) and Sedláček (2010) conclude that there is no difference between accounting for productive animals and other fixed tangible assets since at initial recognition they are measured at acquisition/production cost and in financial statements they are carried at historical cost less depreciation and impairment. Krupová (2012) analysed the Slovakian experience and they argue that annual depreciation for animals of the core herd can be accounted for and assumes that inclusion of depreciation in the production costs creates a reserve for rebuilding the core herd. Whereas in Bulgaria, where biological assets are classified as productive and consumable biological assets producing agricultural products, depreciation is calculated for bearer plants only (Georgieva, 2017; Georgieva, 2016). 
In the USA, depreciation accounting for productive animals, e.g., dairy cows, is neglected since the obtained residual value fails to correctly reflect the real value of the cow in any rearing year (Newport, 2015). Kuzub (2016) suggests that depreciation accounting for the main herd is unreasonable as that results in a systematic decrease in the animal residual value, whereas measuring biological assets at fair value takes into account the animal weight, prices, years of rearing, etc. The results of research conducted by Visberg (2016) also provide evidence that depreciation for dairy cows was not calculated in any of the 72 Estonian enterprises they examined. According to those authors, measuring the residual value of those animals is difficult.

In Germany, acquired animals are initially recorded in the financial statements at acquisition cost and subsequently at established standard rates (Krudewig, 2017; Schieder, 2016) but no depreciation is recorded in their financial accounts. In the meantime, Chinese Accounting Standard for Business Enterprises No 5 provides that enterprises have to make the call on the useful life of productive animals, their estimated residual value and the depreciation methods. Those methods include the straight-line method, the units of production method, etc. In financial statements, the cost of those assets is reduced by accumulated depreciation and an impairment loss is recognised (Riccardi, 2016).

According to Lithuanian standards, animals are not depreciated and their book value is recognised as an expense when those assets are sold, slaughtered, or the animals fall, etc. In Czech Republic, depreciation for draught animals and racehorses classified as non-current assets is accounted for each animal, while other animals are depreciated in groups (Sedláček, 2010). In the meantime, Svoboda (2017) and Bohušová (2017), who investigated the relevance of the cost method to measure the value of dairy cows, calculated depreciation for each individual animal.

Biological asset depreciation accounting is relevant not only in financial accounting but also in tax accounting. The currently valid version of the Law on Corporate Income Tax of the Republic of Lithuania provides that cost can be charged to expenses only for bearer plants. For the purpose of profit tax, the acquisition/production cost of all other current or non-current biological assets is recognised as an expense only when productive or consumable biological assets are sold, slaughtered, or the animals fall, etc.

For German tax purposes, the acquisition/production cost of animals attributable to non-current assets is capitalised and amortised over their estimated useful life. Animals recorded as current assets are measured at acquisition/production cost, which is recognised as an expense when they are sold. However, several alternatives for charging low-value non-current assets to expenses were introduced on 1 January 2011 (Krudewig, 2017; Schieder, 2016). For tax purposes, depreciation shall be calculated for productive animals, the acquisition/production cost whereof is higher than EUR 410. Productive animals recorded as non-current assets, the acquisition/production cost whereof is under EUR 410, do not need to be depreciated and their whole acquisition/production cost, including the residual value, can be recognised immediately as an expense in the year in which the asset is put into service. This is 
particularly relevant for pig and poultry holdings and egg producers (Höhere Abschreibungsmöglichkeiten ..., 2014).

Demir (2015) notes that the Turkish Law on Tax Procedure establishes the requirement to depreciate productive animals, while their useful life and depreciation rate are estimated depending on the type of biological asset. According to the Chinese tax law, depreciation accounting for productive biological assets shall start next month after the assets are recognised as productive. After productive biological assets are written off, depreciation accounting for those assets stops next month after the assets are written off. Once the residual value of a biological asset is determined, it can no longer be changed. For the purpose of tax accounting, there is a minimum productive biological asset depreciation period, e.g. 10 years for a forest as a productive biological asset, 3 years for productive domestic animals (Cao 2011).

The analysis of research results, international accounting standards and national legislation of accounting in different countries shows different opinions regarding productive animal depreciation accounting and mostly they emphasise that depreciation is calculated for tax purposes only. That suggested the need to analyse the issues related to animal depreciation accounting in more detail and to assess the impact of depreciation on the financial standing and overall performance of the undertakings concerned. In the light of the performed analysis of scientific literature and practical experience with regard to the depreciation accounting for animals, the present work seeks to conduct a case study based on analytical data from agricultural business organisations and to assess the impact of the accounting of animals at their acquisition (production) cost less depreciation to the financial results and economic return of agricultural businesses.

The research aimed at answering the following questions:

- What impact does depreciation accounting for productive animals have on the financial standing and overall performance of an undertaking concerned?

- What effect does depreciation accounting for productive animals have on the key financial ratios that reflect the financial attractiveness of the business concerned?

The methodological framework of the research is based on the agency (Deegan, 2003) and positive accounting (Watts, 1990) theories and the main accounting principles. The methods and techniques used for the case study include a case study, analysis of analytical source (primary documents and accounting registers) data, and calculation and analysis of selected financial ratios to assess the effect of animal depreciation on the book values of animals and significance of the indicators. The present investigation describes animal classification and problems resulting from depreciation accounting for productive animals, compares changes in the book value of those assets in the context of the impact of depreciation of productive animals on the book value of assets, and analyses the impact of depreciation on the financial statements of the undertakings concerned and on selected key financial ratios. This research expands and are suitable with the results of previous scientific research aimed at analysing theoretical and analytical aspects of setting up accounting policies for 
biological assets. The study ends with logical insights into expediency of depreciation accounting for animals classified as non-current assets.

\section{Data and methods}

The conducted case study aimed at using actual data to check and justify the expediency of productive animal depreciation. Three Lithuanian agricultural enterprises specialising in different areas were randomly chosen for the research. The profitability of the companies also varied. The research used analytical data and information on biological assets supplied in the financial statements of those agricultural enterprises. All analysed enterprises were engaged in crop and animal production. They measured biological assets at acquisition/production cost presented in the balance sheet. The actual cost of agricultural produce obtained from biological assets, one kilogram of live weight of animals was determined at the end of the reporting period, and it comprised direct and indirect production costs.

One of the randomised enterprises (AE A) specialised in meat and dairy production. Its productive animals were 160 dairy cows and its food-producing animals were 231 cattle for fattening and calves. In the analysed reporting year, the enterprise earned a majority of its revenue from the sales of livestock products (milk) and livestock. In the analysed year, the enterprise was operating at a loss.

The second enterprise (AE B) was in the business of mixed livestock production. It was farming productive animals - 686 dairy cows and 592 sows - and foodproducing animals -1316 cattle for fattening and calves and 10197 pigs for fattening. In the analysed year, the business of the enterprise was profitable.

The key business area of the third enterprise (AE C) was cattle farming for beef production. Its productive animals included 103 suckler cows and 7 bulls for breeding, while food-producing animals were 99 beef cattle calves. In the analysed year, the business of the enterprise was profitable.

The research aimed at evaluating the implications of depreciation for productive animals for information presented in the statements, overall performance and the key financial ratios, which reflect the economic return of a business concerned and provide information material to the owner, investor, creditor and other users of financial information in relation to the value creation process and effective functioning of the enterprise. With reference to Martirosianiene (2016), the analysed key financial ratios that best reflect the implications of depreciation included Current Ratio, Quick Ratio, Total Debt Ratio, Gross Profit Margin, Net Profit Margin, Return on Assets, Asset Turnover, Fixed Asset Turnover Ratio, Current Asset Turnover.

To determine the effect of depreciation for productive animals, we calculated the change in the carrying amount of animals, the cost of production and sales of agricultural produce obtained from productive animals and the cost of live weight of sold and fallen stock. For that purpose, depreciation for productive animals was calculated for all three agricultural enterprises. A retrospective method was used to calculate depreciation and to disclose information, i.e. in restatement of the residual value of productive animals for the beginning of the accounting year it was assumed 
that the linear depreciation method was used. Depreciation was calculated from the first day of the next month after the animals were transferred to the group of productive animals. In cattle farms depreciation was accounted for each animal, while the object of depreciation for sows was pig groups where sows were grouped by the year of birth. The estimated useful life of animals was based on the actual experience of the enterprises: an average of 5 years for dairy cows, 7 years for suckler cows, and 4 years for sows. In revaluation of productive animal cost and residual value, it was assumed that at the time of animal transfer to cows, bulls for breeding or sows their cost was equal to the cost at the beginning of the analysed accounting year. It was also assumed that in-calf heifers are averagely transferred to cows at the age of 2.5-3, young male bovine animals are transferred to bulls for breeding and gilts are transferred to sows on average at the age of 1 . In the reporting year, the cost of animals transferred to the productive animal group was not restated and they were measured at the actual cost of live weight current at the enterprises in the accounting year as the animal production costs for all animals kept for rearing and fattening were pooled together.

\section{Research results}

To compare the effect of measuring animals at cost and depreciation accounting for productive animals on the financial standing and economic return of the undertakings concerned, we calculated the change in the carrying amount of animals of each enterprise where productive animals are measured at cost method and they are either depreciated or not. The change in the book value was measured for each group of animals at the beginning and the end of the reporting period. Information on changes in the carrying amounts of animals resulting from depreciation for productive animals is presented in Table 1.

Table 1. Changes in book value of animals when productive animals are depreciated compared to book value of animals when productive animals are not depreciated, \%

\begin{tabular}{|l|c|c|c|c|c|c|}
\hline \multirow{2}{*}{ Animal groups } & \multicolumn{2}{|c|}{ AE A } & \multicolumn{2}{c|}{ AE B } & \multicolumn{2}{c|}{ AE C } \\
\cline { 2 - 7 } & $\begin{array}{c}\text { Beginning } \\
\text { reporting } \\
\text { period }\end{array}$ & $\begin{array}{c}\text { End of the } \\
\text { reporting } \\
\text { period }\end{array}$ & $\begin{array}{c}\text { Beginning } \\
\text { of the } \\
\text { reporting } \\
\text { period }\end{array}$ & $\begin{array}{c}\text { End of the } \\
\text { reporting } \\
\text { period }\end{array}$ & $\begin{array}{c}\text { Beginning } \\
\text { of the } \\
\text { reporting } \\
\text { period }\end{array}$ & $\begin{array}{c}\text { End of the } \\
\text { reporting } \\
\text { period }\end{array}$ \\
\hline Dairy cows & -32.9 & -31.1 & -18.2 & -15.6 & $\mathrm{x}$ & $\mathrm{x}$ \\
\hline Calves & 0.9 & 2.0 & 2.1 & -3.8 & $\mathrm{x}$ & $\mathrm{x}$ \\
\hline $\begin{array}{l}\text { Dairy cattle, } \\
\text { total }\end{array}$ & -15.4 & -15.9 & -10.9 & -11.5 & $\mathrm{x}$ & $\mathrm{x}$ \\
\hline Sows & $\mathrm{X}$ & $\mathrm{x}$ & -19.7 & -9.6 & $\mathrm{x}$ & $\mathrm{x}$ \\
\hline Piglets & $\mathrm{X}$ & $\mathrm{x}$ & - & 1.0 & $\mathrm{x}$ & $\mathrm{x}$ \\
\hline Pigs, total & $\mathrm{X}$ & $\mathrm{x}$ & -6.2 & -2.3 & $\mathrm{x}$ & $\mathrm{x}$ \\
\hline $\begin{array}{l}\text { Bulls for } \\
\text { breeding }\end{array}$ & $\mathrm{X}$ & $\mathrm{x}$ & $\mathrm{x}$ & $\mathrm{x}$ & -33.4 & -39.1 \\
\hline Suckler cows & $\mathrm{X}$ & $\mathrm{x}$ & $\mathrm{x}$ & $\mathrm{x}$ & -29.1 & -38.1 \\
\hline Beef calves & $\mathrm{X}$ & $\mathrm{x}$ & $\mathrm{x}$ & $\mathrm{x}$ & - & 15.5 \\
\hline $\begin{array}{l}\text { Beef cattle, } \\
\text { total }\end{array}$ & $\mathrm{X}$ & $\mathrm{x}$ & $\mathrm{x}$ & $\mathrm{x}$ & -15.6 & -20.2 \\
\hline Total animals & -15.4 & -15.9 & -10.9 & -8.8 & -15.6 & -20.2 \\
\hline
\end{tabular}


The results presented in the table revealed that in the analysed year, when the depreciation accounting was introduced, the trends of change in the book value of animals at the three enterprises concerned differed. In the analysed reporting period, a decrease in the productive book value of animals related to animal depreciation ranged from 8.8 percent to 20.2 percent. The factor with the main downward effect was the retrospective restatement of depreciation for productive animals as that resulted in a decrease in the book value of animals at the beginning of the period by $10.9-15.6$ percent and affected the value of the property at the end of the reporting period.

The biggest decrease in the book value of animals was observed at the enterprise engaged in cattle farming for beef production. In the meantime, the change in the book value of those assets at enterprises engaged in dairy cow and calf farming followed different patterns and the decrease in book value in one of them ranged from 15.6 to 18.2 percent, while at the other enterprise the decrease in the bovine book value of animals accounted for more than 31 percent. The least significant changes in the book value of animals were observed at the enterprise engaged in mixed livestock production, where at the end of the reporting period depreciation accounting triggered a fall in the book value of pigs of only 2.3 percent.

In the analysed accounting year, the amounts of depreciation for productive animals in dairy cow and suckler cow farms ranged from 6.3 to 7.8 percent of the maintenance costs of those animals, while in the enterprise engaged in pig farming the amounts of depreciation for sows accounted for 1.2 of pig rearing costs.

The altered book value of biological assets resulting from productive animal depreciation is reflected in the financial statements of the companies. When reflected in the profit and loss statement, the depreciation for productive animals in the reporting period has a direct effect on the items of the cost of goods sold (due to changes in the book value of the animals and milk sold), general and administrative expenses (due to changes in the cost of fallen animals and poor-quality milk recognised as an expense) and the profit or loss for the accounting period.

Changes in the profit (loss) lead to changes in items of the statement of financial position - the retained earnings of the previous and current periods. The readjustment of the carrying amount of animals has a direct impact on the amounts in the balance sheet items presenting biological assets. Information on changes in financial statement items resulting from productive animal depreciation compared to the previous book values where productive animal depreciation was not accounted for is presented in Table 2. 
Table 2. Changes in items of the statements of financial position and loss and profit when productive animals are depreciated compared to values when productive animals are not depreciated, $\%$

\begin{tabular}{|c|c|c|c|c|c|c|}
\hline Indicators & \multicolumn{2}{|c|}{ AE A } & \multicolumn{2}{|c|}{ AE B } & \multicolumn{2}{|c|}{$\mathrm{AEC}$} \\
\hline \multicolumn{7}{|c|}{ Profit and loss account for the accounting year } \\
\hline Cost of goods sold & \multicolumn{2}{|c|}{-0.17} & \multicolumn{2}{|c|}{-0.24} & \multicolumn{2}{|c|}{0.32} \\
\hline $\begin{array}{l}\text { General and } \\
\text { administrative } \\
\text { expenses }\end{array}$ & \multicolumn{2}{|c|}{0.12} & \multicolumn{2}{|c|}{0.23} & \multicolumn{2}{|c|}{-0.25} \\
\hline Net profit (loss) & \multicolumn{2}{|c|}{10.6} & \multicolumn{2}{|c|}{3.02} & \multicolumn{2}{|c|}{-4 times } \\
\hline $\begin{array}{l}\text { Statement of } \\
\text { financial position }\end{array}$ & $\begin{array}{l}\text { End of } \\
\text { the } \\
\text { previous } \\
\text { reporting } \\
\text { period }\end{array}$ & $\begin{array}{l}\text { End of the } \\
\text { reporting } \\
\text { period }\end{array}$ & $\begin{array}{l}\text { End of } \\
\text { the } \\
\text { previous } \\
\text { reporting } \\
\text { period }\end{array}$ & $\begin{array}{l}\text { End of the } \\
\text { reporting } \\
\text { period }\end{array}$ & $\begin{array}{l}\text { End of } \\
\text { the } \\
\text { previous } \\
\text { reporting } \\
\text { period }\end{array}$ & $\begin{array}{l}\text { End of the } \\
\text { reporting } \\
\text { period }\end{array}$ \\
\hline Biological assets & -11.2 & -13.6 & -9.4 & -8.8 & -9.4 & -11.5 \\
\hline Stocks & -9.5 & -9.2 & -4.4 & -3.8 & -5.1 & -6.6 \\
\hline Total assets & -3.4 & -3.3 & -2.3 & -1.9 & -2.6 & -3.3 \\
\hline $\begin{array}{l}\text { Previous year's } \\
\text { profit (loss) } \\
\text { brought forward }\end{array}$ & -21.8 & -20.9 & -7.2 & -6.7 & $\mathrm{x}$ & $\mathrm{x}$ \\
\hline $\begin{array}{l}\text { Profit (loss) } \\
\text { brought forward }\end{array}$ & -20.9 & -21.2 & -6.7 & -5.6 & -21.9 & -71 times \\
\hline
\end{tabular}

The presented data show that depreciation for productive animals gave rise to minor changes in the cost of goods sold and general and administrative expenses of the analysed enterprises (their increase or decrease ranged from 0.12 to 0.32 percent), however the economic outturn of the accounting year, as compared to the actual data, at two enterprises demonstrated a more significant improvement (the profit at $\mathrm{AE} \mathrm{B}$ increased by 3 percent, and the loss at $\mathrm{AE} A$ decreased by 10.6 percent). In the meantime, AE C failed to remain profitable (the actually earned profit was EUR 1016) and became loss-making (a loss of EUR 3015), which was the result of the increased cost of goods sold.

Although the book value of all biological assets at the analysed enterprises reduced (the decrease ranged from 8.8 to 13.6 percent), the change in the productive animal accounting policy led to a insignificant reduction of the overall book value of all assets at all analysed enterprises and the variation, as compared to the actual data of the enterprises, accounted for $1.9-3.4$ percent.

The greatest impact on the variation in retained earnings was made by the retrospective restatement of depreciation for productive animals, which resulted in a reduction in the profits brought forward ranging from 6.7 to 21.8 percent that had an important impact on the overall variation in the profit brought forward both at the beginning and at the end of the reporting period, since the outturn demonstrated only insignificant change.

To assess the potential impact of depreciation accounting for productive animals on the financial attractiveness of the business concerned it was chosen to calculate and 
compare the key financial ratios - solvency (liquidity and stability) and profitability and efficiency (negotiability) - for both scenarios, i.e. when productive animals are depreciated or not. In each group, we selected several indicators that best reflect the impact of the said alternatives on them (Table 3).

Table 3. Key financial ratios of agricultural enterprises assessed in two scenarios: when productive animals are depreciated and when they are not

\begin{tabular}{|l|c|c|c|c|c|c|}
\hline \multirow{2}{*}{ Indicators } & \multicolumn{2}{|c|}{ AE A } & \multicolumn{2}{c|}{ AE B } & \multicolumn{2}{c|}{ AE C } \\
\cline { 2 - 7 } & $\begin{array}{c}\text { Productive } \\
\text { animals are } \\
\text { not } \\
\text { depreciated }\end{array}$ & $\begin{array}{c}\text { Productive } \\
\text { animals are } \\
\text { depreciated }\end{array}$ & $\begin{array}{c}\text { Productive } \\
\text { animals are } \\
\text { not } \\
\text { depreciated }\end{array}$ & $\begin{array}{c}\text { Productive } \\
\text { animals are } \\
\text { depreciated }\end{array}$ & $\begin{array}{c}\text { Productive } \\
\text { animals are } \\
\text { not } \\
\text { depreciated }\end{array}$ & $\begin{array}{c}\text { Productive } \\
\text { animals are } \\
\text { depreciated }\end{array}$ \\
\hline Current Ratio & 38.209 & 38.427 & 3.354 & 3.341 & 2.522 & 2.563 \\
\hline Quick Ratio & 9.802 & 9.802 & 0.281 & 0.281 & 0.656 & 0.656 \\
\hline Total Debt Ratio & 0.0087 & 0.0090 & 0.278 & 0.284 & 0.300 & 0.310 \\
\hline $\begin{array}{l}\text { Gross Profit } \\
\text { Margin, \% }\end{array}$ & 13.6 & 13.8 & 11.3 & 11.5 & 12.4 & 12.2 \\
\hline $\begin{array}{l}\text { Net Profit Margin, } \\
\%\end{array}$ & -1.18 & -1.05 & 6.88 & 7.09 & 0.06 & -0.19 \\
\hline $\begin{array}{l}\text { Return on Assets, } \\
\%\end{array}$ & -0.45 & -0.42 & 4.07 & 4.27 & 0.05 & -0.14 \\
\hline $\begin{array}{l}\text { Asset Turnover } \\
\text { Ratio }\end{array}$ & 0.381 & 0.394 & 0.591 & 0.602 & 0.726 & 0.751 \\
\hline $\begin{array}{l}\text { Fixed Asset } \\
\text { Turnover }\end{array}$ & 0.570 & 0.601 & 1.001 & 1.032 & 1.521 & 1.664 \\
\hline $\begin{array}{l}\text { Current Asset } \\
\text { Turnover }\end{array}$ & 1.151 & 1.145 & 1.441 & 1.446 & 1.217 & 1.368 \\
\hline
\end{tabular}

Analysis of the solvency ratios of the agricultural enterprises concerned shows that depreciation accounting for productive animals resulted in different changes in the current ratio, i.e. at two enterprises it increased by 0.6-1.6 percent, as compared to the alternative when productive animals were not depreciated. Whereas the quick ratio of all the enterprises remained unchanged since the change in the productive animal accounting policy prompted an equal change in the book value of stocks and current assets on the balance sheets of the enterprises and consequently this change did not affect the quick ratio.

The total debt ratio in the investigated companies evidences a low (AE A) or very low (AE B and $\mathrm{AE} \mathrm{C}$ ) financial risk. This risk increases when the depreciation for non-current biological assets is accounted for, since the debt indicator increases by approximately 2-3 percent.

The analysis of the profitability rates revealed mixed results. Depreciation accounting for productive animals resulted in a light increase in both gross profit margin (1.5-1.8 percent) and net profit margin (3-11 percent) at $\mathrm{AE} \mathrm{A}$ and $\mathrm{AE} \mathrm{B}$ and a decrease in profitability rates at AE C. That correlates with the aspects highlighted in the analysis of financial statements, i.e. that at some companies productive animal 
depreciation leads to a reduction in the cost of goods sold but an increase in the general and administrative expenses, while at other companies we can see the opposite and therefore the economic outturn of the enterprises changes in varied ways.

Analysis of the asset turnover ratios at the investigated agricultural enterprises shows that at all companies depreciation accounting for productive animals results in an increase in the asset turnover ratio ranging from approximately 3.1 to 9.4 percent, as compared to the same ratios in the situation when productive animals are not depreciated. In the meantime, fixed asset turnover ratios demonstrate variable changes across the enterprises: an increase by 3.5 and 12.4 percent at $\mathrm{AE} \mathrm{B}$ and $\mathrm{AE} \mathrm{C}$, and a decrease by 0.5 percent at $\mathrm{AE} \mathrm{A}$.

It was found that in order to improve the solvency (i.e. liquidity and stability) and to reduce financial risks of all investigated enterprises, the most attractive alternative from the financial perspective was to waive the calculation of depreciation for productive animals.

From the results of the research it appears that it is irrelevant to depreciate productive animals if animals are measured at cost as that has no material impact on the book value of assets, the economic outturn and the key financial ratios of the enterprises and requires to elaborate the accounting of the animal production costs, which sometimes is irrational or even impossible (e.g. in the case of suckler cows), the depreciation amounts fail to take into account changes in animal productivity and economic value.

\section{Conclusions and discussion}

Analysis of international and national accounting regulations and scientific literature leads to a conclusion that there is a diversity of opinions regarding classification of animals as current or non-current assets and their depreciation accounting when these assets are measured at cost. Depreciation for animals classified as non-current assets is usually calculated for tax purposes only. The case study conducted at selected enterprises revealed problems related to depreciation of biological assets. It appeared that given the particular nature of biological assets it is difficult to define the useful life and residual value, which confirmed the conclusions made by Visberg (2016). Due to insufficient productivity, diseases, and other circumstances productive animals can be discarded from the productive animal group prematurely or, on the contrary, animals can be used much longer than the intended useful life if their reproductive characteristics are good. For instance, at the analysed enterprises 2-8 percent of dairy cows and approximately 11 percent of suckler cows were used longer that the estimated life-time, whereas about 14 percent of cows transferred to the dairy cow group were rejected the same year and written off in the non-current assets. Furthermore, measuring the residual value of animals seems to be especially problematic since, for instance, gilts are transferred to sows when their weight is about $180 \mathrm{~kg}$, whereas they are written off from sows when their weight is 
around $280-290 \mathrm{~kg}$ and therefore the depreciation amounts per one animal in the reporting period can be rather small.

The amounts of depreciation for animals classified as non-current assets reduce the residual value of those assets, which fails to correctly reflect the real value of the animals in any rearing year. The economic benefits of productive animals and change in their book value are related to animal productivity. In order to maximise economic benefits, productive herds are in a constant process of change. The research results show that the analysed enterprises demonstrate a rational establishment of productive herds where the numbers of animals transferred to a productive herd and written off are not significantly different. For example, in the analysed period the number of animals transferred to the dairy cow group in dairy cow farms was about 9-13 percent greater than the number of dairy cows written off from this group, while at the enterprise engaged in pig farming in the analysed year the number of animals written off from the sow group was 8.5 percent higher than the number of animals transferred to this group. A continuous natural change in productive herds leads to the conclusion that the maintained optimum herd productivity and the economic benefits of productive animals continues to be relatively stable. Although the specific value of each animal changes, the overall book value of the whole productive herd when animals are measured at cost reflects the actual book value of animals on the balance sheet. That suggests a conclusion that the provision established in the Accounting Directive 2013/34/EU according to which the purchase price or production cost of non-current assets with limited useful economic lives shall be reduced by value adjustments calculated to write off the value of such assets systematically over their useful economic lives, does not take into account the particular nature of biological assets related to the productivity and change in the economic value of such assets. Similar conclusions have been drawn by Kuzub (2016) and Newport (2015), who argued that with depreciation accounting of productive animals a systematic reduction of the residual value of animals fails to reflect the real value of the animals in the rearing year when the animal productivity is growing. On the other hand, the amounts of depreciation for productive animals are included in the cost of agricultural produce or new biological assets obtained therefrom and, according to Georgieva (2017), the competitiveness of those product is reduced.

The conducted research is suitable with the results of previous scientific research as it revealed the impact of the alternatives of depreciation accounting for productive animals on the key financial ratios of the pilot enterprises. It was found that in order to improve the solvency (i.e. liquidity and stability) and to reduce financial risks at all investigated enterprises, the most attractive alternative from the financial perspective was to measure animals at cost and to waive the depreciation accounting for productive animals. No previous research demonstrating the impact of choosing to depreciate or not to depreciate animals on financial indicators has been found. Further research can be related to a longer research period, the number of productive animals, their productivity, etc. 


\section{Management Theory and Studies for Rural Business and Infrastructure Development \\ eISSN 2345-0355. 2019. Vol. 41. No. 2: 213-227. \\ Article DOI: 13https://doi.org/10.15544/mts.2019.18}

\section{References}

Accounting Directive 2013/34/EU. $\quad-\quad$ https://eur-lex.europa.eu/legalcontent/EN/TXT/?uri=celex\%3A32013L0034 [15 12 2018].

Aryanto, Y. H. (2011). Theoretical failure of IAS 41. - http://ssrn.com/abstract=1808413 [05 $012019]$.

Audit and Accounting Service. (2014). For determining fair value. Summary of the survey results. $\quad-\quad$ http://www.avnt.lt/kita/apklausos/auditas-ir-apskaita/audito-ir-apskaitos-tarnybosapklausos-d-l-tikrosios-vert-s-nustatymo-apzvalga/ [06 01 2019].

Bohušová, H., Svoboda, P., Nerudova, D. (2012). Biological assets reporting: is the increase in value caused by the biological transformation revenue // Agricultural Economics. No. 58: 520-532.

Bohušová, H., Svoboda, P. (2014). What does the implementation of IFRS for SMEs bring for agricultural enterprises? // Universitatis Agriculturae et Silviculturae Mendelianae Brunensis. No. 59(7): 81-90.

Bohušová H., Svoboda P. (2017). Biological Assets: Impact of Measurement on Financial Position and Performance of SMEs // Forum Scientiae Oeconomia. No. 5(1): 19-31.

Botosan, C. A., Huffman, A. A. (2015). Decision-useful asset measurement from a business valuation perspective // Accounting Horizons. No. 29(4): 757-776.

Business Accounting Standard - BAS 17 - Biological Assets = Verslo apskaitos standartas VAS 17 - Biologinis turtas. - http://www.bankrotodep.lt/assets/Veiklos-sritys/Apskaita/VAS/Priimtistandartai/17-VAS-5-redakcija.pdf [16 02 2019].

Cao, F. (2011). Corporate Income Tax Law and Practice in the People's Republic of China. - New York: Oxsford University Press, (Chapter 6). 526 p.

Deegan, C. (003). Financial Accounting Theory. Roseville, NSW:McGraw-Hill. 441 p.

Demir, E. (2015). A Look at the Accountancy in Turkish Agriculture in Terms of International Accountancy Standards // International Journal of Academic Research in Business and Social Sciences. No. 5(7): 52-70.

Feleagă, L., Feleagă, N., Raileanu, V. (2012). Theoretical considerations about implementation of IAS 41 in Romania // Theoretical and Applied Economics. No. 2(2): 31-38.

Fischer, M., Marsh, T. (2013). Biological assets: financial recognition and reporting using US and international accounting guidance // Journal of Accounting and Finance. No. 13(2): 57-74.

Gjoni (Karameta), A., Dika, I., Kalemi, F. (2013). Problems and accounting aspects of agricultural companies in terms of global financial crisis // International Journal of Ecosystems and Ecology Sciences. No. 3(4): 753-756.

Georgieva, E. (2016). Options for reporting of depreciation of fixed biological assets according to IAS 41 Agriculture // Economics and computer science. No. 2: 15-22.

Georgieva, E., Penev, N. (2017). Accounting opportunities for depreciation of a cow herd // Trakia Journal of Sciences. No. 15(1): 223-228.

Gonçalves, R., Lopes, P., Craig, R. (2017). Value relevance of biological assets under IFRS // Journal of International Accounting, Auditing and Taxation. No. 29: 118-126.

Höhere Abschreibungsmöglichkeiten für Tierzüchter. (2014). https://www.pressebox.de/pressemitteilung/ecovis-ag-steuerberatungsgesellschaft/HoehereAbschreibungsmoeglichkeiten-fuer-Tierzuechter/boxid/664256 [26 02 2019].

Huffman, A. A. (2016). Asset use and the decision-usefulness of fair value measurement: evidence from IAS 41. - https://papers.ssrn.com/sol3/papers.cfm?abstract_id=2529974 [18 02 2019]

International Accounting Standard - IAS 41 - Agriculture. International Accounting

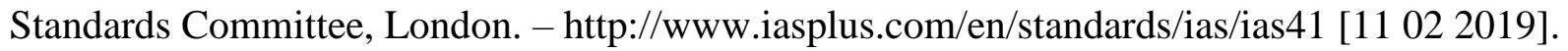

Yazarkan, H. (2016). Accounting process for government grants in hazelnut production within the Framework of international accounting standards: Turkey sample // International Journal of Academic Research in Accounting, Finance and Management Sciences. No. 6(3): 37-46. 


\section{Danutė Zinkevičienè, Neringa Stončiuvienè, Dalia Juočiūnienè, Ingrīda Jakušonoka. Depreciation of animals and economic return: case study}

Krudewig, W. (2017). Diese steuerlichen Abschreibungen stehen bei Wirtschaftsgütern zur Wahl. - https://www.haufe.de/finance/jahresabschluss-bilanzierung/steuerliche-abschreibungen-beiwirtschaftsguetern_188_394042.html [09 03 2019].

Krupová Z., Michaličková M., Krupa E. (2012). Review of methodologies for costs calculating of ruminants in Slovakia // Journal of Central European Agriculture. No. 13(3): 426-445.

Kurniawan, R., Mulawarman, A. D., Kamayanti, A. (2014). Biological assets valuation reconstruction: a critical study of IAS 41 on agricultural accounting in Indonesian farmers // Procedia-Social and Behavioral Sciences. No. 164: 68-75.

Kuzub, M. (2016). Ways of Improvement of Accounting of Production Stocks in Agricultural Enterprises // Research Papers of the Wroclaw University of Economics. No. 434: 79-91.

Law on Corporate Income Tax of the Republic of Lithuania. Seimas of the Republic of Lithuania. 20 December 2001. No IX-675. seimas.lrs.lt/portal/legalAct/lt/TAD/TAIS.273770?jfwid=ck9gyaymo [08 01 2019].

Martirosianienè L., Stončiuvienė N., Zinkevičienè D. (2016). Accounting Policy Formation by Agricultural Business Entities to Increase Financial Attractiveness: Research Monograph = Žemès ükio verslo subjektu apskaitos politikos formavimas siekiant finansinio patrauklumo: mokslo monografija. Akademija. 296 p.

Newport, A. (2015). Real cow depreciation isn't the same as Uncle Sam's. http://www.beefproducer.com/blogs-real-cow-depreciation-isnt-same-uncle-sams-9776 $\left[\begin{array}{ll}02 & 02\end{array}\right.$ 2019].

Ocnean M., Balan I., Marin, D. (2017). Practical Aspects on the Application of International Accounting Standards 41 - Agriculture // Lucrări Ştiinţifice. No. 1(2): 203-208.

Ore, M. (2011). Problematic Aspects of Accounting for Biological Assets // Economic science for rural development. Proceedings of the International Scientific Conference. No. 24: 204-210.

Otavova, M., Glaserova, J. (2017). The impact of changes in accounting regulations on agricultural entities and their business accounts since 2016 // Acta Universitatis Agriculturae et Silviculturae Mendelianae Brunensis. No. 65(2): 689-697.

Pop, A., Deaconu, S. C. (2008). Assets. Biological Assets. The Seasonal Model in agriculture. Theoretical and Applied Economics. No. 7(7): 3-18.

Riccardi, L. (2016). China Accounting Standards. Introduction and Effects of New Chinese Accounting Standards for Business Enterprises. Springer Singapore, (Chapter 9). 337 p.

Rozentāle, S., Ore, M. (2013). Evaluation of biological assets: problems and solutions // Journal of Modern Accounting and Auditing. No. 9(1): 57-67.

Sava, R. (2014). Accounting for Biological Assets // Revista Economică. No. 66(5): 101-111.

Schieder, S. (2016). Die richtige Abschreibung nach Steuerrecht. https://www.stuttgart.ihk24.de/Fuer-Unternehmen/recht_und_steuern/steuerrecht/Einkommen_und_Koerperschaftssteuer/AfA_Tabelle/676428 [21 11 2018].

Scott, D., Wingard, C., Van Biljon, M. (2016). Challenges with the financial reporting of biological assets by public entities in South Africa // South African Journal of Economic and Management Sciences. No. 19(1): 139-149.

Sedláček, J. (2010). The Methods of Valuation in Agricultural Accounting// Agricultural Economics - Czech. No. 56(2): 59-66.

Svoboda, P., Bohušová, H. (2017). Amendments to IAS 16 and IAS 41: Are There Any Differences between Plant and Animal from a Financial Reporting Point of View? // Acta Universitatis Agriculturae et Silviculturae Mendelianae Brunensis. No. 65(1): 327-337.

Vazakidis, A., Stergios, A., Laskaridou, E. (2010). The importance of information through accounting practice in agricultural sector-european data network // Journal of Social Sciences. No. 6(2): 221-228.

Watts, R. L., Zimmerman, J. L. (1990). Positive Accounting Theory: a Ten Year Perspective // The Accounting Review. American Accounting Association. No 65(1): 131-156. 


\title{
GYVŪNŲ NUSIDE்VE்JIMO ĮTAKA EKONOMINEI GRĄŽAI: ATVEJO ANALIZÉ
}

\author{
*Danutė Zinkevičienè ${ }^{1}$, Neringa Stončiuvienè ${ }^{2}$, Dalia Juočiūniené ${ }^{\mathbf{3}}$, Ingrīda Jakušonoka \\ ${ }^{1,2,3}$ Vytauto Didžiojo universitetas, ${ }^{4}$ Latvijos žemès ūkio universitetas
}

\section{Pateikta 201905 31; priimta 20190630}

Vertinant ūkyje auginamus gyvūnus ịsigijimo (pasigaminimo) savikainos būdu, vyrauja skirtinga praktika dèl šio turto nusidèvejjimo skaičiavimo. Moksliniuose tyrimuose keliami klausimai: ar reikia skaičiuoti žemės ūkio veikloje naudojamų gyvūnų nusidèvėjimą; ar visiems, ar tik daliai gyvūnų reikia skaičiuoti nusidèvėjimą; nuo kokios vertès turi būti skaičiuojamas nusidèvèjimas ir pan. Pristatomu tyrimu, kuris pagrịstas atsitiktinès atrankos būdu pasirinktų įmonių analitiniais duomenimis, siekta ịvertinti, kokią ịtaką gyvūnų ịkainojimas savikaina ir šio turto nusidèvejjimas turi jų kuriamai ekonominei grąžai ir žemès ūkio verslo subjekto veiklos rezultatams bei finansinei būklei. Tyrimo metu paaiškejjo, kad sunku nustatyti konkretaus gyvūno naudingo naudojimo laiką ir likvidacinę vertę, gyvūnų savikainos laipsniškas nurašymas skaičiuojant nusidèvèjimą neįvertina biologinio turto ypatumų dèl šio turto produktyvumo ir jų ekonominès vertès kitimo. Siekiant padidinti mokumą bei sumažinti finansinę riziką, finansiškai patraukliausia alternatyva buvo gyvūnus îkainoti ịsigijimo (pasigaminimo) savikainos būdu ir neskaičiuoti šio turto nusidèvèjimo.

Raktiniai žodžiai: gyvūnu klasifikacija,, gyvūnu matavimas, kainu matavimas, nusidèvèjimas fimnancinis stabilmas, veiksmingumas.

JEL Codes: D24, M41, Q14.

\footnotetext{
* Autorius pasiteirauti
} 